ORIGINAL ARTICLE

\title{
Optimal selective logging regime and log landing location models: a case study in the Amazon forest
}

\author{
Paulo Henrique da SILVA ${ }^{1}$, Lucas Rezende GOMIDE ${ }^{1 *}$, Evandro Orfanó FIGUEIREDO², \\ Luis Marcelo Tavares de CARVALHO ${ }^{1}$, Antônio Carlos FERRAZ FILHO ${ }^{3}$ \\ Universidade Federal de Lavras, P.O. Box 37, Zip Code 37200-000, Lavras, Minas Gerais, Brazil \\ 2 Embrapa, Rodovia BR-364, Km 14, Zip Code 69900-970, Rio Branco, Acre, Brazil \\ 3 Universidade Federal do Piauí, Av. Manoel Gracindo, km 01, Zip Code 64900-000, Bom Jesus, Piauí, Brazil \\ * Corresponding author: lucasgomide@dcf.ufla.br
}

\begin{abstract}
Reduced-impact logging is a well known practice applied in most sustainable forest management plans in the Amazon. Nevertheless, there are still ways to improve the operational planning process. Therefore, the aim of this study was to create an integer linear programming (ILP) to fill in the knowledge gaps in the decision support system of reduced impact logging explorations. The minimization of harvest tree distance to wood log landing was assessed. Forest structure aspects, income and wood production were set in the model, as well as the adjacency constraints. Data are from a dense ombrophylous forest in the western Brazilian Amazon. We applied the phytosociological analysis and BDq method to define the selective logging criteria. Then, ILP models were formulated to allow the application of the constraints. Finally, 32 scenarios (unbalanced forest, UF, and balanced forest, BF) were generated and compared with real executed plans (RE). Robust results were achieved and the expected finding of each scenario was met. The feasibility to integrate ILP models in uneven-aged forest management projects was endorsed. Consequently, the UF and BF scenarios tested were efficient and concise, introducing new advances for forest management plans in the Amazon. The proposed models have a high potential to improve the selective logging activities in the Amazon forest.
\end{abstract}

KEYWORDS: forest planning, reduced-impact logging, integer linear programming, sustainable forest management, Liocourt quocient

\section{Regime de corte seletivo ótimo em modelos de locação de pátios de estocagem de madeira: um estudo de caso na floresta amazônica}

\section{RESUMO}

A exploração de impacto reduzido é uma prática bem conhecida e aplicada na maioria dos planos de manejo florestal sustentável na Amazônia. Todavia, ainda há a possibilidade de melhoria do processo de planejamento da operação. Diante da falta de métodos auxiliares à tomada de decisão, o objetivo do trabalho foi desenvolver modelos de programação linear inteira (PLI) para suprir esta demanda. Considerou-se a minimização da distância entre as árvores exploradas e os pátios de estocagem de madeira. Aspectos estruturais, econômicos e produtivos foram incorporados ao modelo, bem como restriçóes de adjacência. Os dados derivam de uma floresta ombrófila densa na Amazônia Ocidental. Previamente, utilizou-se uma análise fitossociológica e o método BDq como critério de remoção. Posteriormente, modelos de PLI foram formulados para exemplificar as aplicaçóes. Finalmente, 32 cenários (para floresta desbalaceada, UF, e floresta balanceada, BF) foram gerados e comparados com o plano executado no campo (RE). Resultados robustos foram obtidos e atenderam às expectativas de cada cenário. A viabilidade da integraçáo dos modelos de PLI em projetos de manejo de florestas ineqüiâneas foi testado. Os cenários UF e BF testados foram eficientes e concisos, confirmando seu potencial para aumentar a eficiência de planos de exploração madeireira e manejo florestal na Amazônia.

PALAVRAS-CHAVE: manejo florestal, exploração de impacto reduzido, programação linear inteira, manejo florestal sustentável, quociente de Liocourt 


\section{INTRODUCTION}

Natural uneven-aged forests represent a population in different age levels, with diverse diameter/height structures and floristic composition resulting from the interaction between edaphic and climatic factors. These forests have economic potential when properly managed, mostly due to high quality timber production, among other uses (Hanewinkel et al. 2014). The Amazon forest is the largest rainforest in the world, spreading over nine South-American countries and holding the largest reserve of natural resources and diversity of the planet (Silva et al. 2005; Vieira et al. 2005; Pereira et al. 2010). The forest sector contribution to the economy of the Amazon region is about 10.12 billion dollars (2009), and is responsible for approximately 204.000 jobs associated with harvest activities, transportation, wood processing and commercial businesses (SFB and IMAZON 2010). However, it is possible to identify many gaps in the wood supply chain. Important forest harvesting damages are wood waste and impact to the remaining forest. The forest harvest activity is responsible for 30\% (7\% logging, 3\% log skidding, 4\% damage trees, $6.6 \%$ skid trails, and $9.4 \%$ clearing) of negative impacts in the remnant trees (Pinto et al. 2002). Generally, the harvest planning process is carried out without considering ecological criteria thus contributing to increase the high ecological impacts on the managed forests, and consequent economic losses due to reduced remaining timber stocks (Hendrison 1990; Almeida 1996; Rocha et al. 2007). It is estimated that the major cause of forest degradation in the tropics is unplanned selective logging (Mazzei et al. 2010).

Reduced-impact logging (RIL) is a well known practice applied in sustainable forest management plans in the Amazon. There is mounting evidence to show how these techniques guarantee the best forest structure after logging (Chheng et al. 2015), although it remains a challenge to achieve a balance between the logging industry and conservation efforts (Gatti et al. 2015). RIL has scientific and engineering principles that involve worker education and training (Medjibe et al. 2011). The GPS technology and remote sensing are used to control and evaluate field work or mitigate forest damages (Marvin et al. 2016). Due to the high operational complexity and costs of selective logging, mathematical programming models are effetive aids in planning and executing logging routines (Braz et al. 2004; Gomide et al. 2010, Fernandes et al. 2013), but have yet to be implemented as widespread optimization tools in selective logging enterprises in the Brazilian Amazon. Thus, the objective of this study was to develop integer linear programming (ILP) models to minimize the distance between harvested trees and the planned log landings, integrating the BDq method, economical aspects, adjacency constraints and wood production parameters.

\section{MATERIAL AND METHODS}

\section{Study area}

The study was conducted in Porto Acre, in the north of Acre state, in the southwestern Brazilian Amazon, in a 470.038 ha area of sustainable forest management (Figure 1). The vegetation is a mix of palm trees and Dense Ombrophilous Forest (EMBRAPA 2011). According to the Köppen climate classification, the region has a tropical monsoon climate $(\mathrm{Am})$ marked by intense rainfall (total annual precipitation ranging between $1.900 \mathrm{~mm}$ and $2.000 \mathrm{~mm}$ ) and average annual temperature ranges from $24.8^{\circ} \mathrm{C}$ to $25^{\circ} \mathrm{C}$ (Gomes 2009).

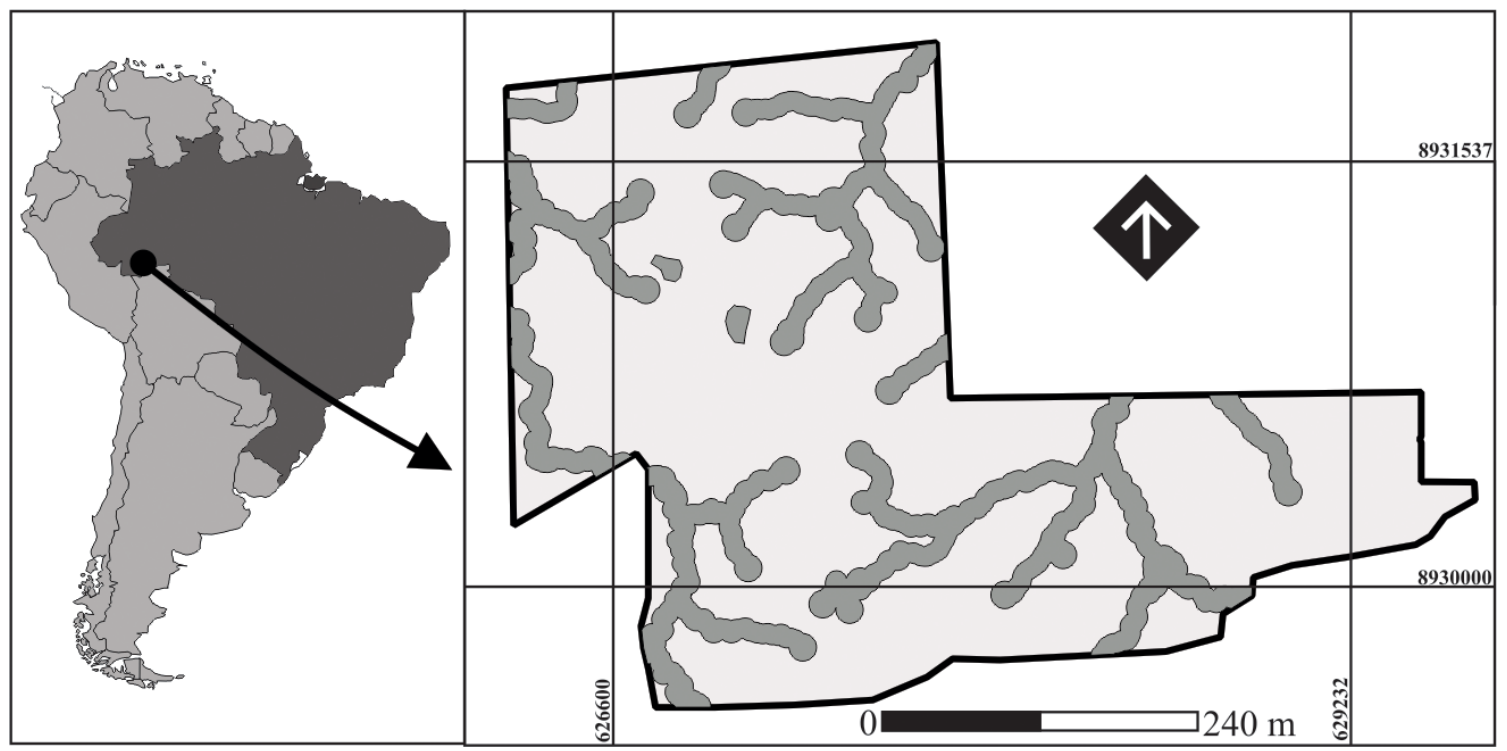

Figure 1. Location of the study area in a sustainably managed forest in Porto Acre, state of Acre, in the southwestern Brazilian Amazon. 
A forest inventory was carried out in the area to quantify all commercial trees with diameter at breast height $(\mathrm{DBH})$ higher than or equal to $50 \mathrm{~cm}$, acquiring commercial height, botanical identification, and geographical coordinates of each tree. The volume of each tree was estimated by $\hat{V}_{i}=-2.38578+7.74023 D_{i}^{2}+0.207944 H D_{i}^{2}+0.16146 H_{i}$ as proposed by EMBRAPA (2011), where: $\mathrm{V}=$ tree estimated volume $\left(\mathrm{m}^{3}\right) ; \mathrm{D}=$ diameter at breast height $(\mathrm{cm})$ and $\mathrm{H}=$ commercial height $(\mathrm{m})$, with $\mathrm{R}^{2}=97.51 \%$ and residual standard error $= \pm 0.8393 \mathrm{~m}^{3}$.

A phytosociological analysis was used to analyze the relational pattern among species and describe the forest structure. Our aim was to discriminate the rare species from those available for logging by using absolute and relative density and dominance values. The pre and post harvest values of the Shannon diversity and Pielou equability indexes were also analyzed. After determining the species suitable to be harvested we quantified the Liocourt's constant "q" value. This relationship generates a geometric series from the diameter distribution, defined as the ratio of number of trees in a given diameter class and the number of trees in the next diameter class (Watzlawick et al. 2013). The constant value "q" was derived from the Meyer model (equation 1), where: $Y_{i}=$ number of trees per hectare from the class $i ; \beta_{0}, \beta_{1}=$ parameters to be estimated and $x_{i}=$ central value of diameter class $i$.

$\ln \left(Y_{i}\right)=\beta_{0}+\beta_{1} x_{i} \pm e_{i}$

According to Brazilian legislation the maximum volume that can be harvested in the Amazon forest is $21.5 \mathrm{~m}^{3} \mathrm{ha}^{-1}$ in a 25 year cycle. However, in our analysis we adopted the removal of $50 \%$ of basal area (BA) to be harvested from the original forest (the total BA in the management area is 1000.98 $\mathrm{m}^{2}$ ). These criteria are required for the BDq method (where $\mathrm{BA}=$ basal area, $\mathrm{D}=$ maximum diameter, and $\mathrm{q}=$ Liocourt constant), which informs as an output the number of trees to be harvested by species and diameter class. We did not restrict the maximum diameter of the remaining forest in this study. These trees were our mathematical model input and pre-defined by the BDq method.

\section{Log landing plan}

Potential log landing locations were evaluated from a grid mesh of 1 ha placed over the whole forest management area. The proposal was to adopt the center of each grid as a feasible point to install a $\log$ landing of 20 by $25 \mathrm{~m}$. Whenever the center of the grid fell in an unsuitable location (slope higher than 15\% or permanent preservation area) the log landing was excluded. At the end of this stage, 366 possible locations were designated as potential log landings.

An integer linear programming model was then structured, taking into account the classic problem known as facility location problem. The problem uses a binary decision variable $\{0,1\}$ and consists of finding locations for facilities to supply customers so that distance costs are minimized. Mathematically, we assume a Graph $G=(L, T)$, where $L$ is a $\log$ landing set and $T$ the trees. The goal is to find a log landing subset $n p(\mathrm{np} \subset \mathrm{L})$, such that the sum of the distance between trees and $p$ are minimized. There is a set of trees $i$ designated for each active $j \log$ landing, which simulated the operational harvest activity. To describe the proposed model, we use the notation and parameters given in Table 1.

$F O: \operatorname{Min} \quad Z=\sum_{i=1}^{N} \sum_{j=1}^{P} c_{i j} x_{i j}$

St: $\sum_{j=1}^{P} x_{i j} \leq 1 ; \quad \forall_{i}$

$$
\sum_{i=1}^{N} v_{i j} x_{i j} \geq V P M I N_{j} y_{j} ; \quad \forall_{j}
$$

$$
\sum_{i=1}^{N} v_{i j} x_{i j} \leq V P M A X_{j} y_{j} ; \quad \forall_{j}
$$

$$
x_{i j}-y_{j} \leq 0 ; \quad \quad \forall_{i}, \forall_{j}
$$

$$
\sum_{i=1}^{\substack{N \in k \\ N \in l}} \sum_{j=1}^{P} x_{i j} \leq D_{j}^{k l} ; \quad \forall_{k} ; \forall_{l}
$$

$$
\sum_{i=1}^{N \in g} \sum_{j=1}^{P} v_{i} x_{i j} \leq V G_{g} ; \quad \quad \forall_{g}
$$

$$
\sum_{i=1}^{N \in g} \sum_{j=1}^{P} x_{i j} \leq N A_{g} ; \quad \forall_{g}
$$

$$
\sum_{i=1}^{N \in g} \sum_{j=1}^{P} x_{i j} \leq w_{g} g_{g} ; \quad \forall_{g}
$$

$$
\begin{array}{ll}
\sum_{\substack{g=1 \\
g \neq e}}^{M} b_{g e} g_{g}+\left[\sum_{\substack{g=1 \\
g \neq e}}^{M} b_{g e}\right] g_{g} \leq \sum_{\substack{g=1 \\
g \neq e}}^{M} b_{g e} ; & \forall_{e} \\
c_{i j} \geq D_{\max }: \mathrm{x}_{i j}=0 ; & \forall_{i} ; \forall_{j} \\
\sum_{i=1}^{N} \sum_{j=1}^{P} r_{i} x_{i j} \geq \mathrm{R}_{\min } &
\end{array}
$$

$$
x_{i j}=\{0 ; 1\}, \mathrm{y}_{j}=\{0 ; 1\}, \mathrm{g}_{g}=\{0 ; 1\} ; \quad \forall_{i}, \forall_{j}, \forall_{g}
$$


Table 1. Notation and parameters used in all formulated model problems to solve tree selective logging and landing location.

\begin{tabular}{|c|c|}
\hline Notation & Description \\
\hline Z & Vector resulting from the sum of log skidding distance $i$ to log landings $j$. \\
\hline$c_{i j}$ & Log skidding costs (Euclidean distance) between tree $i=\{1,2, \ldots, 1.699\}$ and log landing $j=\{1,2, \ldots, 366\}$. \\
\hline$x_{i j}$ & Binary decision variable $\{0,1\}$ used to skid tree $i$ to log landing $j$. \\
\hline$v_{i j}$ & Tree commercial volume $\left(\mathrm{m}^{3}\right) i$ designed to log landing $j$. \\
\hline N & Total number of inventoried trees. \\
\hline P & Total number of log landings. \\
\hline VPMIN $_{j}$ & Minimum timber volume capacity of log landing $j$. \\
\hline$y_{j}$ & Binary decision variable $\{0,1\}$ to activate log landing $j$. \\
\hline $\operatorname{VPMAX}_{j}$ & Maximum timber volume capacity of the log landing $\left(350 \mathrm{~m}^{3}\right)$. \\
\hline k & Number of diameter classes $k=\{1,2, \ldots, 18\}$ \\
\hline । & Number of species $I=\{1,2, \ldots, 23\}$. \\
\hline$D_{j}^{k l}$ & $\begin{array}{l}\text { Maximum number of trees, identified as species / and diameter class } k \text {, } \\
\text { able to be harvested based on the DBq method and dragged to log landing } j \text {. }\end{array}$ \\
\hline$V G_{g}$ & Maximum timber volume allowed to be explored in grid g $\left(200 \mathrm{~m}^{3}\right)$. \\
\hline $\mathrm{NA}_{\mathrm{g}}$ & Total number of trees to be explored per grid $g$. \\
\hline$w_{g}$ & Total number of trees in grid $g$. \\
\hline$g_{9}$ & Binary decision variable $\{0,1\}$ able to activate or not the harvest in grid $g$. \\
\hline M & Total number of grids. \\
\hline$b_{g k}$ & Coefficient derived from the adjacency binary matrix $\{0,1\}$. \\
\hline e & Grid index of each adjacency matrix row. \\
\hline $\mathrm{D}_{\text {máx }}$ & Maximum log skidding distance (400 m). \\
\hline$r_{i j}$ & Timber selling price of tree $\boldsymbol{i}\left(\mathrm{U} \$ 25.71 \mathrm{~m}^{-3}\right)$. \\
\hline$R_{\text {min }}$ & Minimum income to be obtained at the end of the project (U\$142,857.14). \\
\hline
\end{tabular}

The objective function (2) was formulated to minimize the skidder movement (Euclidian distance) within the forest stand. The initial constraints are also part of the classic model of P-medians, where (3) guarantees that the selected trees $i$ to be dragged to a single log landing $j$ according the forest management plan; (4) and (5) determine the number of log landings to be installed based on minimum and maximum volumes, respectively, and (6) that the harvested tree is only dragged to a single selected log landing.

The next constraints were developed exclusively to integrate the forest management plan principles with the BDq method, as well as economic and ecologic concerns. Initially, the individual density to be harvested according to the diameter class and species was controlled in constraint (7), following the balanced forest structure and the BDq method. We adopted a maximum harvest volume control of $200 \mathrm{~m}^{3}$ per grid in constraint (8). This strategy was used to avoid harvest concentration areas, reduce forest damage and large clearings. Similarly, constraint (9) was generated, but associated to the maximum harvest of 5 trees ha $^{-1}$ per grid $g$. Constraints (10) and (11) avoid adjacent grids $g$ to be harvested simultaneously. A technical constraint (12) was developed to guarantee optimal machine effort limit. A fixed variable (variable assumes value equal to zero) was adopted when the distance between tree $i$ and log landing $j$ was higher than 400 $\mathrm{m}$. Income demands (13) were established as U\$ 142,857.14.

Formally, it is possible to simulate a range of scenarios from the model formulation (equations 2 to 14), as is usually applied in most forest planning models. These variations are used to understand the constraint effects on the economical and ecological aspects of the management plans. Therefore, 32 scenarios were generated by combining the constraints and the objective function. Half of them are associated with no selective logging (UF = unbalanced forest structure) and the other half $(\mathrm{BF}=$ balanced forest structure) is associated with tree selection according to the principles of the Meyer proposal (Kerr 2014). We also compared these scenarios with the real executed (RE) forest management plan. These strategies are summarized in Table 2. Mathematical models were processed using the branch and bound algorithm in Lingo software (version 14.0) on Intel Core i5 3210 $\mathrm{MHz}$ and $4 \mathrm{~Gb}$ RAM computers setting a 24-hour run limit. Due to the hard complexity problem, at the end of this period, we interrupted the processing and assessed the solution reports. 
Table 2. Integer linear programming model formulation used to solve the management problems in the study area of sustainable Amazonian forest management in Acre, Brazil.

\begin{tabular}{|c|c|c|c|c|c|c|c|c|c|c|c|c|c|}
\hline \multirow{2}{*}{ Models } & \multicolumn{13}{|c|}{ Equations } \\
\hline & 2 & 3 & 4 & 5 & 6 & $7^{*}$ & 8 & 9 & 10 & 11 & 12 & 13 & 14 \\
\hline 1 & $x$ & $x$ & $x$ & $x$ & $x$ & $x$ & & & & & & $x$ & $x$ \\
\hline 2 & $x$ & $x$ & $x$ & $x$ & $x$ & $x$ & & & & & $x$ & $x$ & $x$ \\
\hline 3 & $x$ & $x$ & $x$ & $x$ & $x$ & $x$ & & & $x$ & $x$ & $x$ & $x$ & $x$ \\
\hline 4 & $x$ & $x$ & $x$ & $x$ & $x$ & $x$ & & & $x$ & $x$ & & $x$ & $x$ \\
\hline 5 & $x$ & $x$ & $x$ & $x$ & $x$ & $x$ & & $x$ & & & $x$ & $x$ & $x$ \\
\hline 6 & $x$ & $x$ & $x$ & $x$ & $x$ & $x$ & & $x$ & & & & $x$ & $x$ \\
\hline 7 & $x$ & $x$ & $x$ & $x$ & $x$ & $x$ & $x$ & & & & $x$ & $x$ & $x$ \\
\hline 8 & $x$ & $x$ & $x$ & $x$ & $x$ & $x$ & $x$ & & & & & $x$ & $x$ \\
\hline 9 & $x$ & $x$ & $x$ & & $x$ & $x$ & & & & & & $x$ & $x$ \\
\hline 10 & $\mathrm{x}$ & $x$ & $x$ & & $x$ & $x$ & & & & & $x$ & $x$ & $x$ \\
\hline 11 & $x$ & $x$ & $x$ & & $x$ & $x$ & & & $x$ & $x$ & $x$ & $x$ & $x$ \\
\hline 12 & $x$ & $x$ & $x$ & & $x$ & $x$ & & & $x$ & $x$ & & $x$ & $x$ \\
\hline 13 & $x$ & $x$ & $x$ & & $x$ & $x$ & & $x$ & & & $x$ & $x$ & $x$ \\
\hline 14 & $x$ & $x$ & $x$ & & $x$ & $x$ & & $x$ & & & & $x$ & $x$ \\
\hline 15 & $x$ & $x$ & $x$ & & $x$ & $x$ & $x$ & & & & $x$ & $x$ & $x$ \\
\hline 16 & $x$ & $x$ & $x$ & & $x$ & $x$ & $x$ & & & & & $x$ & $x$ \\
\hline
\end{tabular}

${ }^{*}$ not applied in UF scenarios

\section{RESULTS}

Highest density species were Dipteryx odorata (14.12\%), Cedrela odorata (7.60\%), Phyllocarpus riedelii (6.87\%), Terminalia guianensis (6.74\%), Eschweilera odorata (6.61\%), and Apuleia leiocarpa (6.05\%). The remaining $48 \%$ were composed of 35 lower density species. The forest management plan identified 1,909 commercial trees belonging to 41 species, with $12,840.79 \mathrm{~m}^{3}$ of timber volume and $1,000.98 \mathrm{~m}^{2}$ of basal area. However, only 23 species were allowed to be harvested after evaluation and application of all models.

Only 21 feasible solutions were obtained (Table 3), and for those with UF scenarios the feasibility percentages were higher $(90.6 \%)$. This illustrates how balanced forest constraints are hard to meet. On the other side, integer linear models require more processing time and sometimes the solution is not found for hard combinatorial problems.

The UF scenarios reached a minimum required income close to U\$143,000, except for scenario 19 . The BF feasible scenarios earned around U\$31,000 more income for all feasible models. The use of balanced forest constraints forced the harvest of a pre-defined threshold level, which resulted

Table 3. The forest harvest solution associated with the proposed optimization models BF (1-16) and UF (17-32) and its effects on forest diversity, structure, income and wood production.

\begin{tabular}{|c|c|c|c|c|c|c|c|}
\hline \multirow{2}{*}{ Scenarios } & \multirow{2}{*}{ Models } & \multirow{2}{*}{ Shannon index } & \multirow{2}{*}{ Pielou } & \multirow{2}{*}{$N_{h}$} & \multirow{2}{*}{$\frac{B A_{h}}{\left(m^{2}\right)}$} & \multirow{2}{*}{$\frac{\text { Volume }}{\left(\mathrm{m}^{3}\right)}$} & \multirow{2}{*}{$\begin{array}{c}\text { Income } \\
\text { (US\$) }\end{array}$} \\
\hline & & & & & & & \\
\hline 1 & 1 & 3.30 & 0.8896 & 931 & 527.16 & $6,791.92$ & $174,649.4$ \\
\hline 2 & 2 & 3.30 & 0.8896 & 931 & 527.31 & $6,793.85$ & $174,698.9$ \\
\hline 3 & 3 & \multicolumn{6}{|c|}{ infeaseble solution } \\
\hline 4 & 4 & \multicolumn{6}{|c|}{ infeaseble solution } \\
\hline 5 & 5 & \multicolumn{6}{|c|}{ no solution before exceed run time limit } \\
\hline 6 & 6 & \multicolumn{6}{|c|}{ no solution before exceed run time limit } \\
\hline 7 & 7 & 3.30 & 0.8896 & 931 & 527.61 & $6,789.88$ & $174,596.9$ \\
\hline 8 & 8 & 3.30 & 0.8896 & 931 & 527.62 & $6,797.96$ & $174,804.9$ \\
\hline 9 & 9 & 3.30 & 0.8896 & 931 & 527.21 & $6,792.95$ & $174,676.0$ \\
\hline 10 & 10 & 3.30 & 0.8896 & 931 & 527.37 & $6,793.22$ & $174,682.9$ \\
\hline 11 & 11 & \multicolumn{6}{|c|}{ infeaseble solution } \\
\hline 12 & 12 & \multicolumn{6}{|c|}{ infeaseble solution } \\
\hline 13 & 13 & \multicolumn{6}{|c|}{ no solution before exceed run time limit } \\
\hline 14 & 14 & \multicolumn{6}{|c|}{ no solution before exceed run time limit } \\
\hline 15 & 15 & 3.30 & 0.8896 & 931 & 527.32 & $6,793.90$ & $174.700,3$ \\
\hline 16 & 16 & 3.30 & 0.8896 & 931 & 527.24 & $6,791.29$ & $174,633.1$ \\
\hline 17 & 1 & 3.23 & 0.8718 & 563 & 423.47 & $5,555.60$ & $142,857.1$ \\
\hline 18 & 2 & 3.23 & 0.8719 & 563 & 423.61 & $5,555.56$ & $142,857.1$ \\
\hline 19 & 3 & 3.20 & 0.8637 & 340 & 218.40 & $2,819.60$ & 72,503.7A \\
\hline
\end{tabular}


Table 3. Continued

\begin{tabular}{|c|c|c|c|c|c|c|c|}
\hline \multirow{2}{*}{ Scenarios } & \multirow{2}{*}{ Models } & \multirow{2}{*}{ Shannon index } & \multirow{2}{*}{ Pielou } & \multirow{2}{*}{$N_{h}$} & $\mathrm{BA}_{h}$ & Volume & Income \\
\hline & & & & & $\left(m^{2}\right)$ & $\left(m^{3}\right)$ & (US\$) \\
\hline 20 & 4 & \multicolumn{6}{|c|}{ no solution before exceed run time limit } \\
\hline 21 & 5 & 3.23 & 0.8704 & 530 & 422.15 & $5,555.57$ & $142,857.1$ \\
\hline 22 & 6 & 3.23 & 0.8705 & 530 & 422.31 & $5,555.57$ & $142,857.1$ \\
\hline 23 & 7 & 3.23 & 0.8719 & 563 & 423.61 & $5,555.56$ & $142,857.1$ \\
\hline 24 & 8 & 3.23 & 0.8719 & 563 & 423.61 & $5,555.56$ & $142,857.1$ \\
\hline 25 & 9 & 3.23 & 0.8719 & 563 & 423.61 & $5,555.56$ & $142,857.1$ \\
\hline 26 & 10 & 3.23 & 0.8719 & 563 & 423.61 & $5,555.56$ & $142,857.1$ \\
\hline 27 & 11 & \multicolumn{6}{|c|}{ infeaseble solution } \\
\hline 28 & 12 & \multicolumn{6}{|c|}{ infeaseble solution } \\
\hline 29 & 13 & 3.22 & 0.8697 & 524 & 422.18 & $5,555.58$ & $142,857.1$ \\
\hline 30 & 14 & 3.23 & 0.8699 & 527 & 422.46 & $5,555.56$ & $142,857.1$ \\
\hline 31 & 15 & 3.23 & 0.8719 & 563 & 423.61 & $5,555.56$ & $142,857.1$ \\
\hline 32 & 16 & 3.23 & 0.8719 & 563 & 423.61 & $5,555.56$ & $142,857.1$ \\
\hline
\end{tabular}

$\mathrm{Nh}$ - total number of trees harvested, BAh - total of basal area harvested, and A - income limit was reduced to obtain a feasible solution

in improved income. Trees were selected from the forest management plan, and the DBq method suggested how many trees should be harvested per species and diameter classes. The negative exponential distribution is essential to assure these principles and needs to be respected. Therefore, the model defined a higher tree number to be harvested in BF scenarios.

The RE scenario obtained an income of US\$2 240,521.9 from 1,155 harvested trees, which produced $9,355.19 \mathrm{~m}^{3}$ (volume) and $724.05 \mathrm{~m}^{2}$ (basal area). These results were higher than all scenarios tested due to the removal of $68 \%$ of the original basal area. We adopted $50 \%$ of basal area to be harvested, considering that this value yields $68 \%$ of volume, the limit established by the Brazilian legislation. Based on the timber selling price $\left(\mathrm{U} \$ 25.71 \mathrm{~m}^{-3}\right)$ and the real volume harvested in 2011 in the study area, the income differences were U\$ 65,872.5 (UF) and U\$ 97,664.8 (BF). The reduced income achieved was mainly associated to constraint (13) for all scenarios. Actually, the simulated income value of US\$ 142,857 should be modified and the model is robust enough to support the forest management decisions.

For scenarios with adjacency constraints, we obtained only one feasible solution. Even after reducing the requested income limit only scenario 19 (UF) with 14 active log landings and $350 \mathrm{~m}^{3}$ of maximum capacity was successful (Figure 2). The conservation cost of forest neighborhood in scenario 19 was approximately 50\% higher when compared with no adjacency scenarios in UF (e.g., scenario 17). Reduced income rates were observed when adjacency constraints were inserted in the model due to the lower
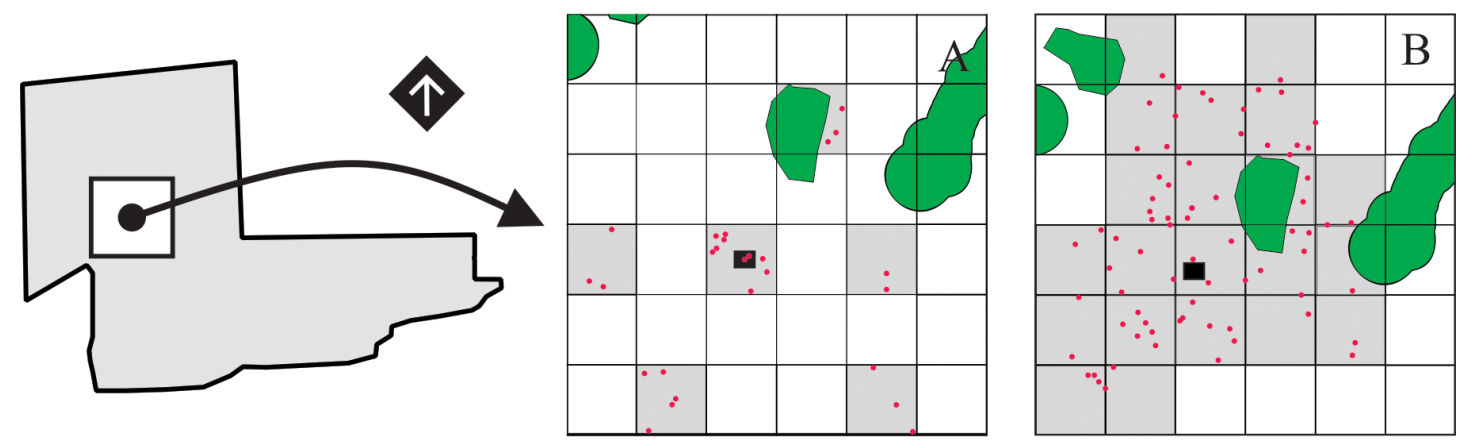

With harvest effect

Log landing

Without harvest effect $\bullet$ Selected tree

Figure 2. Adjacency constraint effect (A) and real execution of the management plan (B) in the study area of sustainable forest management in Acre, Brazil. This figure is in color in the electronic version. 
selected tree density. Constraints (8) and (9) were responsible for the reduction of the clustering in the forest (Figure 3 ). Constraint (8) was more restrictive than (9) in the BF scenarios and unfortunately no solution was found, while all UF scenarios reached feasible solutions. In these scenarios, the total number of active log landings was similar to the real forest management plan.

The use of a fixed variable [constraint (12)] allowed to control the distance drag limit effect (Figure 4). After simulating all scenarios, the Shannon diversity increased from 3.17 to 3.22 after the forest exploration. There was no loss of species richness, because species evenness increased as exploration was concentrated in species with high density.

When analyzing the effect of harvest on tree diameter structure, we observed negative impacts when diameter classes had fewer individuals than the minimum to guarantee the next harvest cycle. Overall, the proposed models of BF scenarios were developed based on these statements and the solutions respect the mathematical concept of the $\mathrm{BDq}$ method (Figure 5).
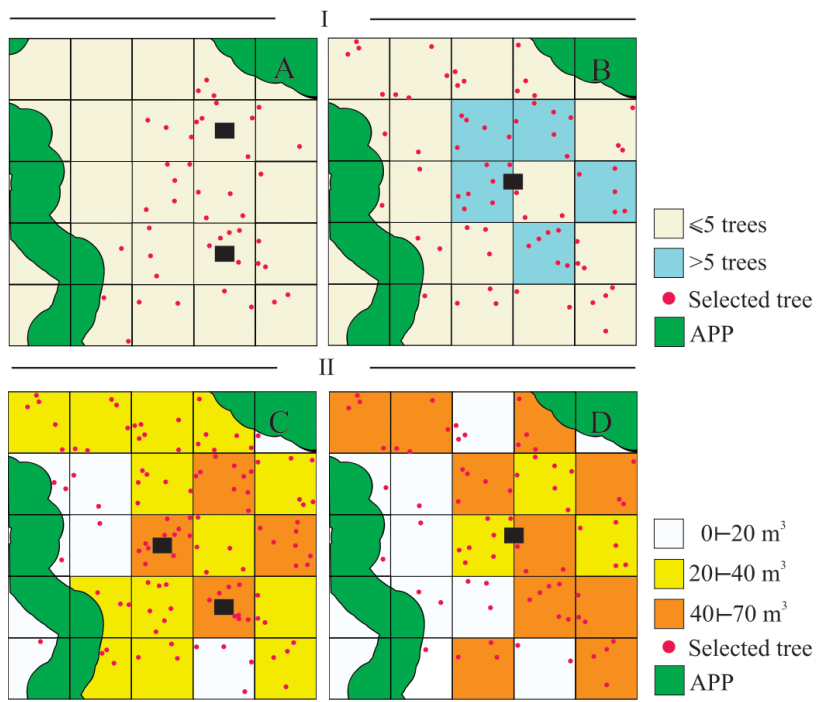

Figure 3. Tree harvest map panels showing the effects of constraints 8 - scenario 22 (A) for number of trees (I), and 9 - scenario 24 (C) for volume (II), when compared with the real execution of the management plan ( $B$ and $D)$ in the study area of sustainable forest management in Acre, Brazil. This figure is in color in the electronic version.

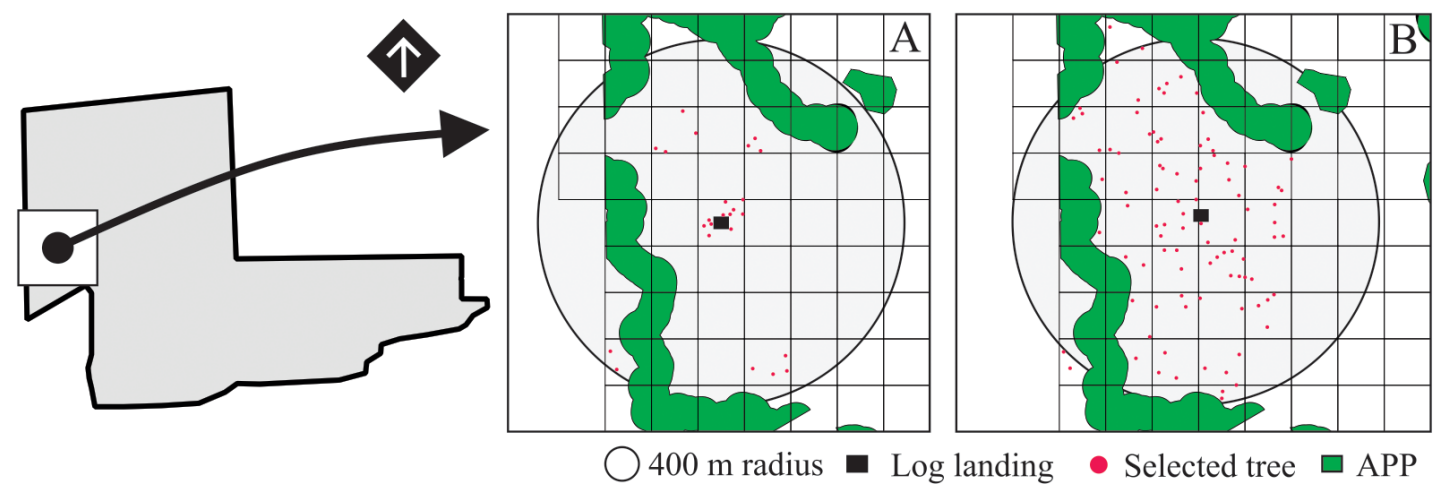

Figure 4. Comparison of fixed variable effect (A) and real execution of management plan (B) in the study area of sustainable forest management in Acre, Brazil. This figure is in color in the electronic version.

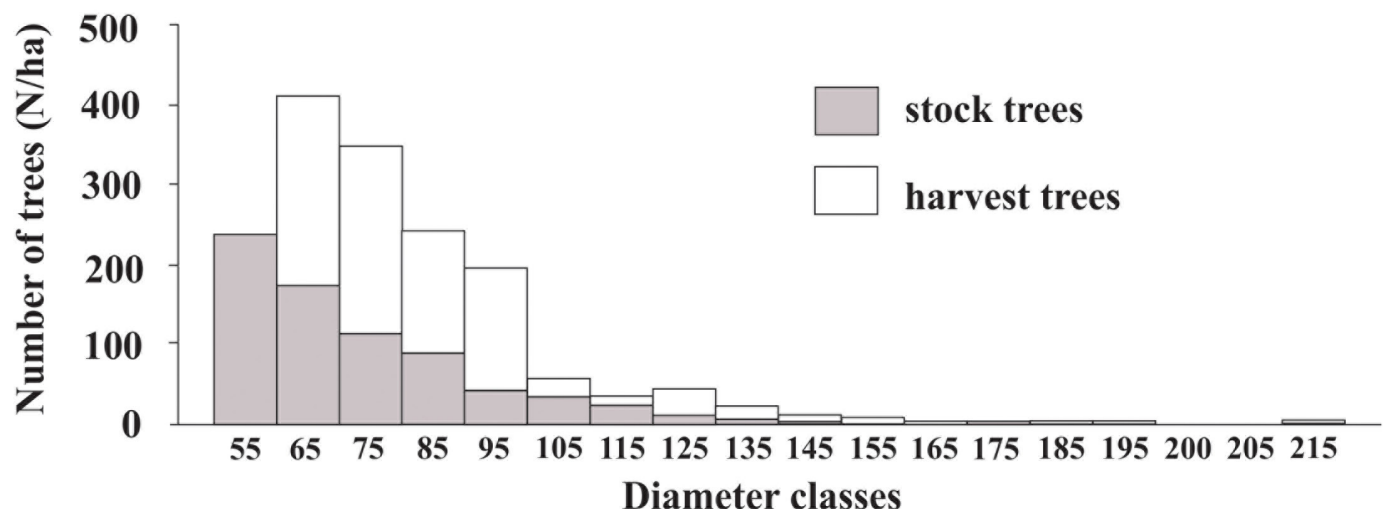

Figure 5. Effect of selective logging in a balanced diametric structure in the remaining forest in the study area of sustainable forest management in Acre, Brazil. 


\section{DISCUSSION}

There are many reasons to adopt selective logging principles in forest management. Keer (2014) brings up an excellent perception about how forest management influences the recovery stock rate and future structure of the forest. Reduced impact logging (RIL) practices are essential to contribute to forest conservation, and their efficiency is affected by logging intensity and harvesting practices, as well as the timber stock level maintained in the forest stand (Medjibe et al. 2011). In our study, the BF and UF models took into account the distance between trees selected to be harvested and log landing location. The objective function was designed to minimize this distance and reduce the residual damage after harvest. Both models were able to solve this problem in a straightforward manner.

The skid trail damage caused by heavy machinery has a highly significant impact on the remaining vegetation after the exploration process (5.4\%, Johns et al. 1996; 3.5\% and 13.2\%, Winkler 1997; 7\%, Sist and Ferreira 2007). Postharvesting silvicultural treatments are required to accelerate the growth of commercial species, and are sometimes crucial to guide the sustainable forest management when the rate of natural regeneration is insufficient (Schulze 2008; Schwartz et al. 2013).

RIL comprises a group of operational activities which include pre and post-harvest forest inventory, individual tree mapping, felling and bucking techniques, accurate delimitation of roads and trails, liana cutting, among others (FAO 2004). RIL produced less disturbances in canopy opening dynamics than conventional logging (CL) (Asner et al. 2004). Aboveground carbon storage capacity and biomass are reduced after selective logging, except in low harvest intensity (Gatti et al. 2015). Our proposed models conform to the RIL scope and contribute to reach an optimum income rate, while it also becomes evident from our results that uneven-aged forest management needs to be better planned before felling and bucking. The constraints applied in our model corroborate the findings of Kuuluvainen et al. (2012) regarding the natural habitat loss.

Our findings highlight the potential importance of including constraints (8) and (9) in all models. These constraints control the number of trees (8) or volume (9) harvested per grid ( $1 \mathrm{ha}$ ). The proposal was to avoid the creation of large clearing areas, which are not desirable in forest management. This technical procedure in our models avoids higher machine effort to drag logs for long distances. Also, it contributes to reduce the vegetation damage across long trails into the forest. In this sense, the impact on the remaining vegetation is less than that observed in the actually implemented forest management plan. This demonstrates the usefulness of, mathematical programming models to aid decision making in forest management plans to optimize timber production as well as standing forest conservation.
Spatial constraints are a way of integrating tree location into mathematical models. Adjacency was incorporated in our models to avoid the harvesting of neighboring stands. The application of adjacency constraints has been used as an effective tool to control landscape damage after harvest activities (Alonso 2003; Castro 2007; Gomide et al. 2013). Gomide et al. (2010) worked with four scheduling scenarios of forest harvesting and adopted the adjacency constraints URM (unit restriction model) and ARM (area restriction model). They also observed the reduction of net present value and volume yield when using adjacency constraints. However, they controlled the harvesting of adjacent stands and avoided large contiguous areas of clearcut. In our study, the adjacency constraints significantly affected the income rate and their use was optional in the model. Therefore, constraint (13) reports the income rate required to balance the impacts of logging on the ecological aspects of the stand. However, considering the post-harvest fragmentation problem, different types of forest management can influence the intensity of edge effect and fire risk (Armenteras et al. 2013). In this sense, the use of spatial constraints can solve a variety of problems such as the maintenance of ecological corridors to connect protected areas, adjacency, habitat protection, and large harvest areas (Augustynczik et al., 2015). Adjacency constraints have been widely used in forest harvest scheduling problems (Borges et. al., 2014).

A greater number of forest optimization analyses are focused on commercial plantations. Uneven-aged forests have greater complexities and challenges on the operational logging level. In this context, the model abstractions should be added to planning as long as they have a significant influence on the results (Pukkala et al. 2014). Our model can be adapted with the inclusion of other parameters to suit different planning necessities. The income constraints should incorporate different timber assortments, prices and demands, not only timber volume sale.

The use of a fixed variable adequately controlled the skidding distance drag. However, some of the trees in our model were dragged across permanent protection areas. This problem was not defined in the model scope but it may be solved by adding penalties in Euclidian distance between the log landing and the trees. The penalties are a constant that increases the distance and objective function when that tree is selected. The model complexity in this study is characteristic of a NP-hard to reach an optimum solution (Daskin and Maass, 2015).

Our results for maximum limit of trees per grid were feasible because all grids were able to be explored with no control of species and diameter class, which we had to remove in order to achieve feasible solutions. On the other hand, the maximum harvested volume limit per grid promoted low impact, which permitted a more flexible model for selective logging and operational harvesting control. The problem observed in these cases is the opening of large clearings, since 
the exploration has been concentrated in specific locations. However, a dense canopy recovery was observed three years after harvest in the same forest type (Francez et al. 2013).

\section{CONCLUSIONS}

Our mathematical models were able to support forest management planning by estimating a reduction in vegetation damage and guaranteeing timber yield regulation in unevenaged forests. Furthermore, we demonstrated that it is possible to integrate an optimum selective logging regime with location log landings. The proposed models have a high potential to improve selective logging activities in the Amazon forest.

\section{ACKNOWLEDGEMENTS}

We are grateful to Coordenação de Aperfeiçoamento de Pessoal de Nivel Superior (CAPES), Empresa Brasileira de Pesquisa em Agropecuária (Embrapa), Universidade Federal de Lavras (UFLA), and the editors' reviews.

\section{REFERENCES}

Almeida, D.S. 1996. Floristica e estrutura de um fragmento de floresta atlântica, no município de Juiz de Fora. Master's dissertation, Universidade Federal de Viçosa, Viçosa, Minas Gerais. 91p.

Alonso, L.R.L. 2003. O problema da consideração de restrições de adjacência em um planejamento florestal. Master's dissertation, Universidade Federal do Paraná, Curitiba, Paraná. 114p.

Armenteras, D.; González, T.M.; Retana, J. 2013. Forest fragmentation and edge influence on fire occurrence and intensity under different management types in Amazon forests. Biological Conservation, 159: 73-79.

Asner, G.P.; Keller, M.; Silva, J.M. 2004. Spatial and temporal dynamics of forest canopy gaps following selective logging in the eastern Amazon. Global Change Biology, 10: 765-783.

Augustynczik, A.L.D.; Arce, J.E.; Silva, A.C.L. 2015. Planejamento espacial da colheita considerando áreas máximas operacionais. Cerne, 4: 649-656.

Borges, P.; Bergseng, E.; Eid, T. 2014. Adjacency constraints in forestry - a simulated annealing approach comparing different candidate solution generators. Mathematical and Computational Forestry \& Natural Resource Sciences, 6: 11-25.

Braz, E.M.; Carnieri, C.; Arce, J.E. 2004. Um modelo otimizador para organização dos compartimentos de exploração em floresta tropical. Revista Árvore, 28: 77-83.

Castro, R.R. 2007. Regulação de florestas equiâneas incluindo restriçôes de adjacência. Master's dissertation, Universidade Federal de Viçosa, Viçosa, Minas Gerais. 64p.

Chheng, K.; Mizoue, N.; Khorn, S.; Kao, D.; Sasaki, N. 2015. Treebased approach to evaluate size dependence of residual tree damage caused by selective logging: Case study in tropical semi-evergreen forests of Cambodia. Forest Ecology and Management, 356: 285-292.

Daskin, M.S.; Maass, K.L. 2015. The p-Median Problem. In: Laporte, G.; Nickel, S.; Gama, F.S. Location Science. Springer, Switzerland, p. 21-45.
Empresa Brasileira de Pesquisas Agropecuárias - Embrapa. 2011. POA - Plano Operacional Anual da Fazenda Rio Brilhante. Embrapa, Rio Branco, Acre. 50p.

Fernandes, A.P.D.; Guimarães, P.P.; Braz, E.M.; Hoeflich, V. A.; Arce, J.E. 2013. Alternativas de planejamento para a exploração florestal. Floresta, 43: 339-350.

Food and Agriculture Organization - FAO. 2004. Reduced impact logging in tropical forests. FAO, Italy. 287p.

Francez, L.M.B.; Carvalho, J.O.P.; Batista, F.J.; Jardim, F.C.S.; Ramos, E.M.L.S. 2013. Influência da exploraçáo florestal de impacto reduzido sobre as fases de desenvolvimento de uma floresta de terra firme, Pará, Brasil. Ciência Florestal, 23: 743-753.

Gatti, R.C.; Castaldi, S.; Lindsell, J.A.; Coomes, D.A.; Marchetti, M.; Maesano, M.; Paola, A.D.; Paparella, F.; Valentini, R. 2015. The impact of selective logging and clearcutting on forest structure, tree diversity and above-ground biomass of African tropical forests. Ecological Research, 30: 119-132.

Gomes, M.A. 2009. Avaliação ambiental na implementação do Empreendimento Sucroalcooleiro na Regiāo de Capixaba, Acre. Doctoral thesis, Universidade Federal de Viçosa, Viçosa, Minas Gerais. 133p.

Gomide, L.R. 2009. Planejamento florestal espacial. Doctoral thesis, Universidade Federal do Paraná, Curitiba, Paraná. 256 p.

Gomide, L.R.; Arce, J.E.; Silva, A.C.L. 2010. Efeito das restriçôes espaciais de adjacência no planejamento florestal otimizado. Floresta, 40: 573-584.

Gomide, L.R.; Arce, J.E.; Silva, A.C.L. 2013. Comparison the metaheuristic Simulated Annealing and Integer Linear Programming for solving the forest harvest scheduling with adjacency constraints. Ciência Florestal, 23: 451-462.

Hanewinkel, M.; Frutig, F.; Lemm, R. 2014. Economic performance of uneven-aged forests analysed with annuities. Forestry: an international journal of forest research, 87: 49-60.

Hendrison, U.J. 1990. Damage-controlled logging in managed tropical rain forest in Suriname. Doctoral thesis, Wageningen Agricultural University, Wageningen, Netherlands. 204 p.

Johns, J.S.; Barreto, P.; Uhl, C. 1996. Logging damage during planned and unplanned logging operations in the Eastern Amazon. Forest Ecology and Management, 89: 59-77.

Kerr, G. 2014. The management of silver fir forests: de Liocourt (1898) revisited. Forestry, 87: 29-38.

Kuuluvainen, T.; Tahvonen, O.; Aakala, T. 2012. Even-Aged and Uneven-Aged Forest Management in Boreal Fennoscandia: A Review. Ambio, 41: 720-737.

Marvin, D.C.; Koh, L.P.; Lynamc, A.J.; Wich, S.; Davies, A.B.; Krishnamurthy, R.; Stokes, E.; Starkey, R.; Asner, G.P. 2016. Integrating technologies for scalable ecology and conservation. Global Ecology and Conservation, 7: 262-275.

Mazzei, L.; Sist, P.; Ruschel, A.; Putz, F.E.; Marco, P.; Pena, W.; Ferreira J.E.R. 2010. Above-ground biomass dynamics after reduced-impact logging in the Eastern Amazon. Forest Ecology and Management, 259: 367-373.

Medjibe, V.P.; Putz, F.E.; Starkey, M.P.; Ndouna, A.A.; Memiaghe, H.R. 2011. Impacts of selective logging on above-ground forest biomass in the Monts de Cristal in Gabon. Forest Ecology and Management, 262: 1799-1806. 
Pereira, D.; Santos, D.; Vedoveto, M.; Guimaraes, J.; Verissimo, A. 2010. Fatos florestais da Amazônia. 1st ed. Imazon, Belém, 124p.

Pinto, A.C.M.; Souza, A.L.; Souza, A. P.; Machado, C.C.; Minette, L.J; Vale, A.B. 2002. Análise de danos de colheita de madeira em Floresta Tropical Úmida sob regime de manejo florestal sustentado na Amazônia Ocidental. Revista Árvore, 26: 459-466.

Pukkala, T.; Lähde, E.; Laiho, O. 2014. Stand management optimization - the role of Simplifications. Forest Ecosystems, 1: 1-11.

Rocha, E.S.; Barros, P.L.C.; Maciel, M.N.; Erler, J. 2007. Avaliação de um sistema operacional de exploraçấo florestal utilizado na Amazônia. Revista Ciências Agrárias, 47: 59-69.

Schulze, M. 2008. Technical and financial analysis of enrichment planting in logging gaps as a potential component of forest management in the eastern Amazon. Forest Ecology and Management. 255: 866-879.

Schwartz, G.; Lopes, J.C.A.; Mohren, G.M.J.; Pena-Carlos, M. 2013. Post-harvesting silvicultural treatments in logging gaps: A comparison between enrichment planting and tending of natural regeneration. Forest Ecology and Management, 293: 57-64.

Serviço Florestal Brasileiro-SFB; Instituto do Homem e o Meio Ambiente da Amazônia-IMAZON. 2010. A atividade madeireira na Amazônia brasileira: produção, receita e mercados. 1st ed. Imazon, Belém, 20p.
Silva, J.M.C.; Rylands, A.B.; Fonseca, G.A.B. 2005. The Fate of the Amazonian Areas of Endemism. Conservation Biology, 19: 689-694.

Sist, P.; Ferreira, F.N. 2007. Sustainability of reduced-impact logging in the Eastern Amazon. Forest Ecology and Management, 243: 199-209.

Vieira, I.C.G; Silva, J.M.C.; Toledo, P.M. 2005. Estratégias para evitar a perda de biodiversidade na Amazônia. Estudos Avançados, 19: 153-164.

Watzlawick, L.F.; Gardin, E.; Longhi, S.J.; Andrade, E.C.L. 2013. Estimate of the diameter distribution in Mixed Ombrophylous Forest fragment with the Meyer's function. Applied Research \& Agrotechnology, 6: 29-36.

Winkler, N. 1997. Report of a case study on "environmentally sound forest harvesting": testing the applicability of the FAO Model Code in the Amazon in Brasil. Draft Report, Food and Agriculture Organization of the United Nations, Rome, 59p.

RECEIVED: 07/11/2016

ACCEPTED: 15/09/2017

ASSOCIATE EDITOR: Francesco Ripullone 